\title{
PEDOMAN PENULISAN
}

Naskah ditulis tidak boleh melebihi 10 halaman dengan menggunakan spasi 1, Arial Narrow, pada kertas A4 dengan margin atas $3 \mathrm{~cm}$ dan $2.5 \mathrm{~cm}$ untuk tiga margin lainnya.

JUDUL (ditulis dalam bahasa Indonesia dan Inggris, tidak melebih 25 kata, Arial Narrow, 14 pt, Bold, Center)

${ }^{1}$ Penulis ${ }^{*}$, ${ }^{2}$ enulis (Arial Narrow, 12 pt, Bold, Center, tidak menggunakan gelar)

${ }^{1}$ Institusi, Kota, Kode pos, Negara (Arial Narrow, 10 pt, Center)

2 Institusi, Kota, Kode pos, Negara (Arial Narrow, 10 pt, Center)

*Koresponden authors: Emai@gmail.com, Telp: +62 (Arial Narrow, 10 pt, Center)

\begin{abstract}
Arial Narrow, $12 \mathrm{pt}$, center, miring)
Abstrak ditulis tidak boleh melebihi 200-250 kata yang mancakup pendahuluan, tujuan, metode, hasil dan pembahasan, kesimpulan. Abstrak tidak boleh berisi tabel, gambar, referensi dan singkatan. (Arial Narrow, 11 pt, spasi 1, Justify)

Key word : 5-8 kata (harus sesuai abjad)
\end{abstract}

ABSTRAK (Arial Narrow, $12 \mathrm{pt}$, center)

Abstrak ditulis tidak boleh melebihi 200-250 kata yang mencakup pendahuluan, tujuan, metode, hasil dan pembahasan, kesimpulan. Abstrak tidak boleh berisi tabel, gambar, referensi dan singkatan. (Arial Narrow, 11 pt, spasi 1 , Justify)

Kata kunci : 5-8 kata (harus sesuai abjad)

Judul pendek:

PENDAHULUAN (Arial Narrow, 12 pt, center)

Bagian pendaluan mencakup latar belakang penelitian, permasalahan, dan tujuan. (Arial Narrow, 11 pt)

MATERI DAN METODE (Arial Narrow, 12 pt, center)

Bagian ini mencakup lokasi penelitian, metode penelitian yang digunakan, prosedur penelitian, analisis data, dan analisis statistik (Arial Narrow, 11 pt, spasi 1).

Bagian materi dan metode terdiri dari sub bab seperti Lokasi penelitian, Prosedur penelitian, Analisis statistik (Arial Narrow, 11 pt, spasi 1, Italic).

\section{HASIL DAN PEMBAHASAN (Arial Narrow, 12 pt, center)}

Hasil dan pembahasan tidak boleh dipisahkan. Penyebutan hasil yang diperoleh berdasarkan metode yang digunakan. Hindari penyajian data mentah maupun penyajian ganda (misalnya tabel dan grafik). Setiap nilai ratarata data harus diberi deviasi standar. Semua data yang diberikan dalam hasil harus disajikan dalam tabel atau grafik, meskipun beberapa hasil mungkin hanya diberikan dalam teks. Pembahasan dapat dilakukan dengan membandingkan hasil / data yang dilaporkan dengan hasil penelitian lain yang dipublikasikan sebelumnya. Berfokus pada interpretasi hasil daripada pengulangan hasil / data. Persamaan, perbedaan, dan keunikan temuan harus diutamakan. Pembahasan juga harus mensitasi dari tabel atau gambar yang ditulis di bagian hasil. (Arial Narrow, 11 pt, spasi 1, Justify).

Sub judul (Arial Narrow, 11 pt, spasi 1, Italic). 
Bagian ini dapat mencakup tabel dan gambar. Gambar yang digunakan harus diberikan keterangan (Gambar 1, Gambar 2, dst), apabila ada satu gambar yang mencakup banyak keterangan harus diperjelas urutannya (Gambar 1a,b,c). Gambar harus mempunyai resolusi minimal 300 dpi (Arial Narrow, 11 pt, spasi 1, Justify).

Tabel 1. Kelimpahan gastropoda (Arial Narrow, 10 pt, spasi 1, Justify).

\begin{tabular}{lccc}
\hline Jenis gastropoda & Mangrove A & Mangrove B & Mangrove C \\
\hline Gastropoda A & $20 \pm 1$ & $13 \pm 1$ & $14 \pm 2$ \\
Gastropoda B & $10 \pm 1$ & $11 \pm 1$ & $21 \pm 3$ \\
\hline Keran
\end{tabular}

Keterangan : misal $\pm=$ SD (Arial Narrow, 8 pt, spasi 1).

Gambar 1. Gastropoda A (Arial Narrow, 10 pt, spasi 1, Justify).

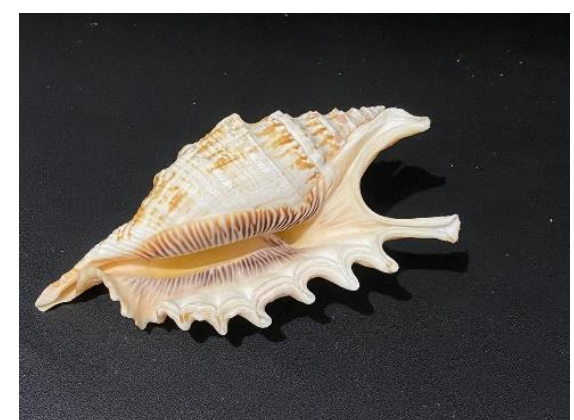

KESIMPULAN (Arial Narrow, 12 pt, spasi 1, Center).

Kesimpulan ditulis dalam satu paragraf yang menjawab hasil dari tujuan penelitian. Bagian ini mencakup temuan yang berimplikasi terhadap hasil penelitian yang dilakuan. (Arial Narrow, 11 pt, spasi 1, Justify).

\section{UCAPAN TERIMA KASIH (Arial Narrow, 12 pt, spasi 1, Center).}

Bagian ini mencakup ucapan terima kasih penulis kepada pihak yang telah membantu dalam penelitian (sumber dana, penggunaan laboratorium). Apabila sumber dana ada nomor surat kontrak penelitian harus dicantumkan (Arial Narrow, 11 pt, spasi 1, Justify).

DEKLARASI (Arial Narrow, 12 pt, spasi 1, Center).

Penulis mendeklarasikan bahwa penulis tidak ada konflik (Arial Narrow, 11 pt, spasi 1, Justify).

DAFTAR PUSTAKA (Arial Narrow, 12 pt, spasi 1, Center).

$\checkmark$ Referensi yang dipergunakan minimal 10 tahun terakhir.

$\checkmark$ Referensi hanya mencantumkan materi yang diterbitkan atau diterima untuk publikasi. Artikel yang diterima tetapi belum diterbitkan harus dikirim sebagai lampiran manuskrip.

$\checkmark$ Referensi harus dicantumkan menurut abjad dengan nama belakang penulis.

$\checkmark$ Penulisan refernsi dalam teks harus mengacu pada nama penulis pertama diikuti tahun terbit dalam tanda kurung, dengan format sebagai berikut: (Lazzeri, 2017) atau Lazzeri (2017), (Pringgenies dan Ariyanto, 2019) atau Pringgenies dan Ariyanto (2019) Jika ada lebih dari dua penulis, gunakan nama penulis pertama diikuti oleh et al., (tidak ditulis miring). Jika beberapa referensi dimasukkan ke dalam tanda kurung yang sama, maka harus diketik dari tahun terlama (Pringgenies dan Yusuf, 2008; Octavina et al., 2015). Jika referensi memiliki tahun yang sama, maka harus disusun menurut abjad. Jika referensi memiliki pengarang yang sama dan tahun yang sama, maka harus dicantumkan dengan memberi huruf kecil a, b, c, dll. Setelah tahun penerbitan.

$\checkmark$ Penulis diperkenankan mensitasi referensi penulis naskah maksimal 5 referensi yang dimiliki.

$\checkmark$ Referensi yang dipergunakan berkisar $15-25$ buah referensi

Contoh penulisan referensi mengikuti berikut: (Arial Narrow, 11 pt, spasi 1, Justify). 
Jurnal

Lazzeri, A. M., Bazihizina, N., Kingunge, P. K., Lotti, A., Pazzi, V., Tasselli, P. L., Fratini, S. (2014). Migratory behaviour of the mangrove gastropod Cerithidea decollata under unfamiliar conditions. Journal of Experimental Marine Biology and Ecology, 457: 236-240. https://doi.org/10.1016/j.jembe.2014.04.024.

Lazzeri, A. M. (2017). Possible environmental chemical cues affecting behaviour of the mangrove gastropod Cerithidea decollata. Estuarine, Coastal and Shelf Science, 188:1217. https://doi.org/10.1016/j.ecss.2017.02.009

\section{Conference Proceedings}

Kurnianda, V., Ramadhan, MR., Karina, S., Agustina, S., Octavina, C., Ulfah, M., Putra Syahliza, F., Faradilla, SB., DF., Purnawan, S., Musman, M. (2019) The inhibitor of human bladder epithelial cancer cells from Indonesian marine sponge of Petrosia sp. IOP Conferences Series: Earth and Environmental Science

Thesis or dissertation

Zulpikar, F. (2010). Aktivitas Peptida Antibakteri dari Hemocyte Kerang Hijau (Perna viridis) Terhadap Vibrio alginoliticus dan Streptococcus iniae. Thesis. Diponegoro Univerisity. Semarang. 132 pp.

Book by editor(s)

Garte, S.J. (Ed). (2000). Molecular environmental Biology. Lewis Publishers. Boca Raton. Florida. 256 pp. 


\section{MASYARAKAT MOLUSKA INDONESIA \\ ISSN 2087-8532}

\section{Jurnal Moluska Indonesia (JMI)}

is a scientific paper dedicated to publishing research papers and highest quality reviews in all aspects of mollusks including ecology, conservation, biodiversity, cultivation, microbiology and biotechnology. 